
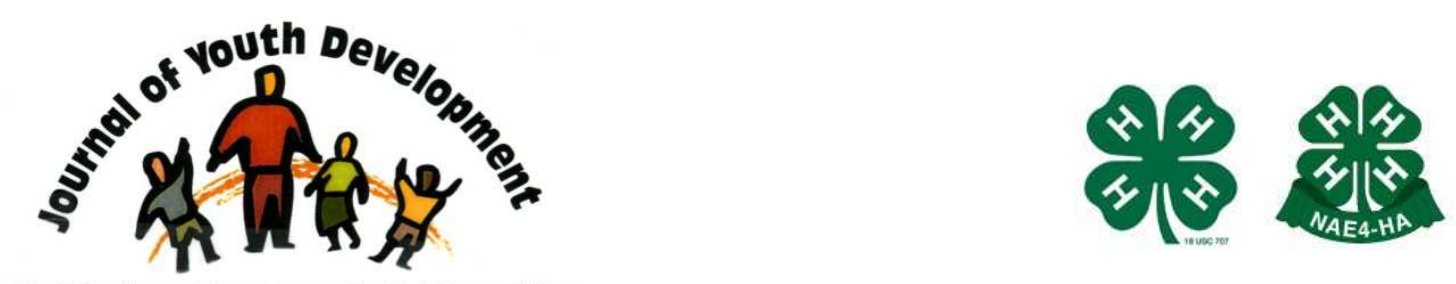

Bridging Research \& Practice

\title{
Measurable Changes in Pre-Post Test Scores in Iraqi 4-H Leader's Knowledge of Animal Science Production Principles
}

\author{
Justen 0. Smith \\ Utah State University \\ Farmington, UT \\ justen.smith@usu.edu \\ Tim Kock \\ Northern Marianas College \\ Saipan, MP \\ Zurishaddai A. Garcia \\ Utah State University \\ Farmington, UT \\ Anvar Suyundikov \\ Utah State University \\ Farmington, UT
}




\title{
JOURNAL OF YOUTH DEVELOPMENT \\ bridging research and practice

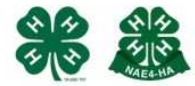

Volume 10, Number 2, Summer2015

Article 151002PA003

\section{Measurable Changes in Pre-Post Test Scores in Iraqi 4-H Leader's knowledge of Animal Science Production Principles}

\author{
Justen O. Smith, Zurishaddai A. Garcia and Anvar Suyundikov \\ Utah State University \\ Tim Kock \\ Northern Marianas College
}

\begin{abstract}
The 4-H volunteer program is a new concept to the people of Iraq, for decades the country has been closed to western ideas. Iraqi culture and the Arabic customs have not embraced the volunteer concept and even more the concept of scientific animal production technologies designed to increase profitability for producers. In 2011 the USAID-Inma Agribusiness program teamed with the Iraq 4-H program to create youth and community entrepreneurship opportunities for widowed families. Iraq 4-H provided the youth members and adult volunteers and Inma provided the financial capital (livestock) and the animal science training program for the volunteers. The purpose of this study was to measure the knowledge level gained through intensive animal science training for Iraqi 4-H volunteers. Researchers designed and implemented a pre and post test to measure the knowledge of fifteen volunteers who participated in the three day course. The pretest exposed a general lack of animal science knowledge of all volunteers; over $80 \%$ of the participants incorrectly answered the questions. However, the post-test indicated positive change in the participants understanding of animal science production principles.
\end{abstract}

\section{Introduction}

Iraq is part of an ancient land that spans the area known historically as Mesopotamia. This part of the world has been home to civilizations since the 6th millennium B.C. Two large rivers, the Euphrates and Tigris, run through Iraq providing the lifeblood to the farmers and livestock producers throughout the country. Over the last eleven years, Iraq has been through a massive military conflict that started in 2003 with the United States invading Iraq and toppling the dictator, Saddam Hussein. This conflict ended in December 2011, but violence continues to 
plague Iraq with hundreds of Iraqi's being killed each year (The New York Times, May 30, 2013).

The years of violence devastated Iraq's infrastructure. Donor agencies throughout the world have spent billions of dollars in rebuilding the country over the past several years. One of those rebuilding projects was a United States Agency for International Development (USAID) funded agricultural development project, entitled the USAID-Inma Agribusiness Development program. Inma means growth in Arabic, something the country will surely realize in the years to come. The USAID-Inma Agribusiness project was responsible for developing agribusiness industries in Iraq such as red meat (livestock), aquaculture, fruits, vegetables, and agriculture marketing. To meet the increasing consumer demand for red meat in Iraq, the USAID-Inma program entered into a partnership with the Iraqi 4-H organization to create opportunities for youth and widows through the development of the 4-H sheep production program. This program would serve as a feeder mechanism for the confined animal feeding program established earlier in Iraq.

According to the National 4-H Council (2013), the 4-H program is an expansive network reaching every corner of the United States and is the largest youth development organization in the U.S. More than 6 million 4-H youth in urban neighborhoods, suburban schoolyards and rural farming communities are building revolutionary opportunities and implementing community wide change at an early age (National 4-H Council, 2013). The 4-H model has been implemented in other countries, but 4-H youth development is a new concept for the culture of Iraq, possibly providing the Iraqi people a path forward. Traditionally youth and adults did not participate in community organizations such as 4-H in Soviet-style, dictator driven countries (Banajanian, B. 2005; Kock, T. 2010).

In 2010, Iraqi 4-H and the USAID-Inma Agribusiness Program established youth-driven 4-H sheep clubs as a means to meet the growing demand of red meat and generate income for rural and marginalized families. These clubs consisted of youth members and adult volunteer leaders, many of whom had never worked with livestock. The volunteers lacked basic animal production knowledge and were ineffective in transferring new technologies (flock management) to youth (USAID-Inma Agribusiness Program, 2010). Therefore, the USAID-Inma program conducted basic three-day animal science intensive courses for the adult volunteers and Inma field staff working with the 4-H clubs.

\section{Purpose of Study}

The purpose of the study was to examine the knowledge change among the Iraqi adult 4- $\mathrm{H}$ volunteer participants of the USAID-Inma animal science short- course training on sheep production.

\section{Objectives of the Study}

For this study, the objectives were:

1. to measure the level of animal science knowledge of participants before the training course;

2. to measure the level of animal science knowledge of participants after the training course;

3. to make recommendations for future training needs based on evaluation results. 


\section{Methods}

The methodology implemented for this study was a pre/post-test research design. An instrument containing 12 multiple choice questions was designed by the researchers and evaluated by a panel of university experts (Iraqi and American) for content then translated into Arabic for ease of understanding by participants. The panel of experts compared the instrument to the course syllabus to ensure that questions asked were covered in course content, thus not asking any question outside of the training program. Iraqi 4-H adult leaders then underwent an intensive 3 day course, 9 hours each day covering all areas of sheep production. A basic overview of Animal Science production principles was also taught. To translate during the courses, Iraqi interpreters were used that had extensive background in Animal Science.

Participants were chosen from provinces across Iraq and consisted of Sunni, Shiite, and Christian Arabs as well as minority Kurds. Each participant completed a pre-test before the course and then provided a post-test after the course. The participants ranged in age from 25 to 55 years old and consisted of 5 females and 10 males. All of the participants had a college education, but had little to no background in livestock production. A $100 \%$ response rate was achieved; all fifteen participants completed both the pre and post instruments. Descriptive statistics were used to analyze the data allowing researchers to draw percentages of correct and incorrect responses for each question and compare the differences between both tests.

\section{Program and Curriculum development}

To prepare for the three day training course, the INMA project management team recruited an American extension agent who was familiar in sheep production, and who had worked in similar conflict environments. One member of the Inma management team (a past American extension faculty and also very familiar with sheep production) along with the newly recruited Extension faculty member developed curriculum that covered areas needed for basic sheep production; animal health, breeding, evaluation, handling, nutrition, and flock management. The respective researchers had over fifty years of combined sheep production experience. These researchers and an Iraqi national staff person working in the livestock sector concluded those topics were important.. The course contained multiple slide presentations, lectures, hands-on analysis of different feeds, and discussion.

The first day covered basic sheep production, reading pharmaceutical labels, filling syringes, and giving injections. To address the topic of giving injections, the instructors used fruit (bananas and oranges) and hands-on demonstration. By peeling the fruit after the injections, the instructors were able to demonstrate how medicine worked on muscle tissue. Each of the participants replicated the process thus learning the difference between subcutaneous, intramuscular, and intravenous.

Day two consisted of lectures covering breeding and nutrition, using slides and teaching aids to add clarity to the lessons. Students were presented slides covering expected progeny differences (EPDs), how to select breeding animals based on the expected performance/purpose, ewe heat cycles and different lambing positions, breach, normal, etc. that may happen during the lambing season. For the nutrition section, the instructors presented slides of different feed stuffs, and actual grains used in feed rations to better understand what a protein feed is and what is an energy feed, and how to design a balanced feed ration using different grains. Each of the participants were asked to design feed rations for different purposes, creep feeding, lactating ewes, finishing lambs, and basic maintenance of flock. 
On the last day of the three day training course, the instructors began putting all of the sections together in order for the participants to fully understand how all of the topics where important for sheep production. The instructors reinforced the importance of animal health, evaluation, handling, and nutrition into profitable sheep production; thus linking those areas together for the participants.

The capstone event for the training course consisted of a mock livestock judging contest using slides for each class of animals judged. The contest covered classes for breeding ewes, replacement ewe lambs, market-type classes and breeding rams. Each section contained three classes of animals and four slides per class. The students worked together to evaluate each class using the description or purpose of the animals as described by the instructors. This methodology allowed participants to apply what had been taught during the last three days, into understanding and application of basic sheep production.

\section{Results}

Pre-test data indicated the majority of respondents incorrectly answered six questions $(2,5,7$, 10, 11 and 12), while 46-60\% of respondents answered pre-test questions, 1, 3, 4, 6, 8 and 9 correctly. Table 1 shows the questions used for the evaluation test instrument along with the questions that were answered correctly.

Table 1

Iraqi 4-H Leader Pre-Test Evaluation Results ( $\mathrm{N}=15)$

\begin{tabular}{|l|l|l|l|l|l|l|}
\hline Question & $\begin{array}{l}\text { Answer } \\
\text { A }\end{array}$ & $\begin{array}{l}\text { Answer } \\
\text { B }\end{array}$ & $\begin{array}{l}\text { Answer } \\
\text { C }\end{array}$ & $\begin{array}{l}\text { Answer } \\
\text { D }\end{array}$ & $\begin{array}{l}\text { Correct } \\
\text { Answer }\end{array}$ & $\begin{array}{l}\text { \% of } \\
\text { participants } \\
\text { answering } \\
\text { correctly }\end{array}$ \\
\hline $\begin{array}{l}\text { 1. Please circle the best } \\
\text { reasons for breeding } \\
\text { problems in ewes }\end{array}$ & 7 & 7 & 0 & 1 & A & 46 \\
\hline $\begin{array}{l}\text { 2. Using the photo of } \\
\text { teeth, identify the proper } \\
\text { age }\end{array}$ & 2 & 1 & 7 & 5 & A & 13 \\
\hline $\begin{array}{l}\text { 3. Please circle the ideal } \\
\text { amount of feed bunk } \\
\text { space for adult sheep }\end{array}$ & 0 & 2 & 2 & 11 & D & 73 \\
\hline $\begin{array}{l}\text { 4. Circle the 2 best } \\
\text { methods for catching } \\
\text { sheep }\end{array}$ & 7 & 2 & 5 & 1 & A & 46 \\
\hline $\begin{array}{l}\text { 5. What is the gestation } \\
\text { period for sheep }\end{array}$ & 0 & 0 & 13 & 2 & D & 13 \\
\hline $\begin{array}{l}\text { 6. Please circle two signs a } \\
\text { ewe is ready to lamb }\end{array}$ & 1 & 9 & 5 & 0 & B & 60 \\
\hline $\begin{array}{l}\text { 7. Please circle one part of } \\
\text { the ruminant stomach }\end{array}$ & 4 & 4 & 7 & 0 & A & 26 \\
\hline $\begin{array}{l}\text { 8. Which of the following is } \\
\text { an energy feed }\end{array}$ & 8 & 2 & 3 & 2 & A & 53 \\
\hline 9. What is the percentage & 3 & 2 & 1 & 9 & D & 60 \\
\hline
\end{tabular}




\begin{tabular}{|l|l|l|l|l|l|l|}
\hline $\begin{array}{l}\text { \%kg a lactating ewe } \\
\text { should eat daily }\end{array}$ & & & & & & \\
\hline $\begin{array}{l}\text { 10. Age of lamb when } \\
\text { started on creep feed }\end{array}$ & 2 & 1 & 9 & 3 & A & 13 \\
\hline $\begin{array}{l}\text { 11. Please circle the proper } \\
\text { location for an IM } \\
\text { vaccination }\end{array}$ & 5 & 5 & 2 & 3 & C & 13 \\
\hline $\begin{array}{l}\text { 12. Please circle the one } \\
\text { disease below that is not a } \\
\text { sheep disease }\end{array}$ & 3 & 7 & 3 & 2 & A & 20 \\
\hline
\end{tabular}

Post-test data indicated all respondents answered questions four and five correctly and 60-86\% answered questions 1, 3, 6, and 12 correctly. Furthermore, data gleaned indicated post-test some respondents continued to struggle by answering questions $2,7,8,9,10$ and 11 incorrectly.

Table 2 shows post-test data results with the percentage of participants answering questions correctly.

Table 2

Iraqi 4-H Leader Post-Test Evaluation Results $(\mathrm{N}=15)$

\begin{tabular}{|l|l|l|l|l|l|l|}
\hline Question & $\begin{array}{l}\text { Answer } \\
\text { A }\end{array}$ & $\begin{array}{l}\text { Answer } \\
\text { B }\end{array}$ & $\begin{array}{l}\text { Answer } \\
\text { C }\end{array}$ & $\begin{array}{l}\text { Answer } \\
\text { D }\end{array}$ & $\begin{array}{l}\text { Correct } \\
\text { Answer }\end{array}$ & $\begin{array}{l}\text { of } \\
\text { participants } \\
\text { correctly }\end{array}$ \\
\hline $\begin{array}{l}\text { 1. Please circle the best } \\
\text { reasons for breeding } \\
\text { problems in ewes }\end{array}$ & 13 & 2 & 0 & 0 & A & 86 \\
\hline $\begin{array}{l}\text { 2. Using the photo of } \\
\text { teeth, identify the proper } \\
\text { age }\end{array}$ & 7 & 7 & 1 & 0 & A & 46 \\
\hline $\begin{array}{l}\text { 3. Please circle the ideal } \\
\text { amount of feed bunk } \\
\text { space for adult sheep }\end{array}$ & 2 & 2 & 0 & 11 & D & 73 \\
\hline $\begin{array}{l}\text { 4. Circle the 2 best } \\
\text { methods for catching } \\
\text { sheep }\end{array}$ & 15 & 0 & 0 & 0 & A & 100 \\
\hline $\begin{array}{l}\text { 5. What is the gestation } \\
\text { period for sheep }\end{array}$ & 0 & 0 & 0 & 15 & D & 100 \\
\hline $\begin{array}{l}\text { 6. Please circle two signs a } \\
\text { ewe is ready to lamb }\end{array}$ & 0 & 12 & 3 & 0 & B & 80 \\
\hline $\begin{array}{l}\text { 7. Please circle one part of } \\
\text { the ruminant stomach }\end{array}$ & 4 & 2 & 9 & 0 & A & 26 \\
\hline $\begin{array}{l}\text { 8. Which of the following } \\
\text { is an energy feed }\end{array}$ & 6 & 8 & 0 & 1 & A & 40 \\
\hline $\begin{array}{l}\text { 9. What is the percentage } \\
\text { \%kg a lactating ewe } \\
\text { should eat daily }\end{array}$ & 1 & 5 & 5 & 4 & D & 26 \\
\hline $\begin{array}{l}\text { 10. Age of lamb when } \\
\text { started on creep feed }\end{array}$ & 1 & 1 & 9 & 4 & A & 6 \\
\hline $\begin{array}{l}\text { 11. Please circle the } \\
\text { nathe }\end{array}$ & 3 & 4 & 7 & 1 & C & 46 \\
\hline
\end{tabular}




\begin{tabular}{|l|l|l|l|l|l|l|}
\hline $\begin{array}{l}\text { proper location for an IM } \\
\text { vaccination }\end{array}$ & & & & & & \\
\hline $\begin{array}{l}\text { 12. Please circle the one } \\
\text { disease below that is not a } \\
\text { sheep disease }\end{array}$ & 9 & 1 & 5 & 0 & A & 60 \\
\hline
\end{tabular}

Although some respondents continued to answer questions incorrectly on the post-test, Table 3 shows an overall increase in knowledge where respondents had the same or increase in knowledge gain on $75 \%$ of the questions.

Table 3

Knowledge Gain Pre-test Compared to Post-test for Iraqi 4-H Leader Evaluations

\begin{tabular}{|c|c|c|c|}
\hline Question & Pre-test\% & Post-test \% & \% increase/decrease in knowledge gain \\
\hline 1 & 46 & 86 & +40 \\
\hline 2 & 13 & 46 & +33 \\
\hline 3 & 73 & 73 & 0 \\
\hline 4 & 46 & 100 & +54 \\
\hline 5 & 13 & 100 & +87 \\
\hline 6 & 60 & 80 & +20 \\
\hline 7 & 26 & 26 & 0 \\
\hline 8 & 53 & 40 & -13 \\
\hline 9 & 60 & 26 & -34 \\
\hline 10 & 13 & 6 & -7 \\
\hline 11 & 13 & 46 & +33 \\
\hline 12 & 20 & 60 & +40 \\
\hline
\end{tabular}

Final data results indicated that participants struggled with the subject of ruminant nutrition, questions 8, 9, and 10 on the post-test show a decrease in knowledge gain. Participants had the correct answers on the pre-test; however, those same participants incorrectly answered those questions on the post-test. Respondents' answers for questions 3 and 7 indicated no knowledge gain from the pre-test to the post-test. All five of these questions dealt with ruminant nutrition. Participants scored highest on questions pertaining to reproduction and general sheep management. To further determine statistical significance the researchers used a t-test for the two dependent (correlated) samples. Our hypotheses:

$H_{0}: \mu$ post $=\mu$ pre

$H_{A}: \mu_{\text {post }}>\mu_{\text {pre }}$

The hypotheses in written explanation is testing to determine whether the overall percentage of participants who answered questions correctly in post-test evaluation is higher than the percentage in pre-test evaluation.

After running a t-test analysis in R (R Development Team Core, 2011), it was determined the $\mathrm{p}$ value was significant $(=0.02576)$, that is less than a threshold of 0.05 . Therefore, we reject the null hypothesis and conclude that the overall percentage of participants who answered questions correctly is higher in post-test evaluation (57.4\%) than in pre-test evaluation (36.3\%). The above output also reaches the $95 \%$ confidence that the mean difference is 3.745 or more. The sample mean difference is reported as $21.08 \%$. 


\section{Recommendations, Educational Importance and Implications}

Based on the findings of this study, most participants (volunteers) initially lacked basic animal science production principles, which would make it extremely difficult for the volunteers to advance the knowledge of 4-H youth livestock producers. Moreover, after completing the animal science short-course participants understanding of livestock production increased significantly. Through the use of several teaching techniques, lecture, slide presentations, hands-on learning, and class discussion, participants understood how to properly read vaccine labels, where (location on the animal) and how to vaccinate animals properly, methods for assisting with lambing problems, and animal evaluation. These are important topics for any livestock production business.

However, the area of ruminant nutrition remained difficult for the participants to grasp. Four content areas remained difficult for participants. Participants continued to answer questions 3, $7,8,9$ and 10 incorrectly, leading the researchers to question if the content presented was too confusing then should have been or the possibility more training was needed in the digestive system of ruminants, creep feeding in lambs, types of feed used for sheep, and amount of feed needed for sheep.

To address the difficulty shown by the participants in different areas of nutrition, the researchers understood that more information was needed by the participants regarding how to apply the information into making sound livestock nutrition decisions in their flocks. The researchers would suggest a separate course be taught covering the many facets of nutrition using more hands-on practical application of creating multiple feed rations for different functions in sheep production. Having students (volunteers) prepare additional and different rations and allow more class discussions of the purpose of each of those rations may create greater understanding of why to use certain feed stuffs, and how each ration increases animal growth. Nutrition plays a very important in livestock production; farmers need a solid understanding of all animal science aspects to ensure better flock management. An additional goal of the researchers was to prepare volunteers to educate 4-H youth in profitable sheep production, however more training is needed in this area. The youth members of those 4-H sheep clubs were out of reach for the Inma field staff, therefore the volunteers needed to be prepared for the role of educator for the youth.

Research conducted by (VanWinkle, Busler, Bowman, \& Manoogian, 2002) indicated that volunteers recognize their need for training and value the opportunity to expand skills and knowledge relevant to their volunteer roles. Hoover and Connor (2001) concluded it is important that volunteers are provided professional development opportunities, which may enhance their ability to be more effective when delivering educational programs. In the international sector, training indigenous people is an important aspect of sustainable development; it provides them the skills needed long after funding sources are gone (Kock, \& Turnbull, 2011). This may certainly be the case in Iraq, volunteering is new to the culture and outside assistance is beginning to decline. Further training concentrating specifically on ruminant nutrition is needed for these adult volunteers and project field staff. Training will expand their knowledge and strengthen their ability to assist Iraqi youth in making the best better.

Extension faculty certainly have the skills to help people in developing countries, those faculty have addressed many of the same issues in their own counties and states using practical application of research based information. These researchers would suggest that those 
interested in working in the international sector, make the effort to contact other university faculty working internationally and or development agencies and express their desire to get involved. Many development agencies have USAID funded Farmer to Farmer volunteer opportunities covering a variety of topics in many parts of the globe. The FtF program is a great way to get started working internationally.

\section{References}

Banajanian, B. (2005). Civic Participation in Post-Soviet Armenia. Central Asian Survey, 24 (3), 261-279.

Kock, T. (2010). Using an Active Learning Approach (the 4-H model) to Stimulate Social Change: Youth and community development in the Republic of Kyrgyzstan. Journal of Youth Development: Bridging Research and Practice, 5(2).

Kock, T., \& Turnbull, J. (2011). Rural Development Centers (Farm Stores) in Afghanistan, Do They Work? The Business Owners' Perspectives. Journal of International Agricultural and Extension Education.18(3).

Hoover, T., \& Connor, N. (2001). Preferred Learning Styles of Florida Association for Family and Community Education Volunteers: Implications for Professional Development. Journal of Extension, 39 (3). Retrieved from http://www.joe.org/joe/2001june/a3.php

National 4-H Council. (2013). 4-H Youth Program is a National Program. Retrieved from http://www.4-h.org/about/youth-development-organization/

R Development Core Team. (2011). A Language and Environment for Statistical Computing. R Foundation for Statistical Computing, Vienna, Austria, 2011. URL http://www.R-project.org/. ISBN 3-900051-07-0.

The New York Times. Iraq: Wave of Violence Continues. (May 30, 2013) Retrieved from http://www.nytimes.com/2013/05/31/world/middleeast/iraq-wave-of-violence-continues.ht.

USAID-Inma Agribusiness Program. (2010). Quarterly Report to USAID Iraq Mission (Baghdad Iraq).

VanWinkle, R., Busler, S., Bowman, S., \& Manoogian, M. (2002). Adult Volunteer Development: Addressing the Effectiveness of Training New 4-H Leaders. Journal of Extension, 40 (6). Retrieved from http://www.joe.org/joe/2002december/a4.php

(C) Copyright of Journal of Youth Development Bridging Research and Practice. Content may not be copied or emailed to multiple sites or posted to a listserv without copyright holder's express written permission. Contact Editor at: patricia.dawson@oregonstate.edu for details. However, users may print, download or email articles for individual use.

ISSN 2325-4009 (Print); ISSN 2325-4017 (Online) 